\title{
Assessment of Patients Knowledge towards Angina Pectoris in Kirkuk City Younis Khider Baez *
}

\begin{abstract}
Background and aim: Angina pectoris is a clinical syndrome usually characterized by episodes or paroxysms of pain or pressure in the anterior chest. The cause is insufficient coronary blood flow, resulting in a decreased oxygen supply when there is increased myocardial demand for oxygen in response to physical exertion or emotional stress. The aim of the study is to assess patient's knowledge toward angina pectoris in Kirkuk city as well as to find out the relation ship between patients knowledge and some Socio- demographic characteristic such as age, gender and level of education
\end{abstract}

Materials and method: A descriptive study of a quantitative design were carried out at Kirkuk general hospital and Azady teaching hospital in Kirkuk city for angina patients from 1st of July, 2012, up to the 16th of April, 2013. A non probability (purposive) sample of (100) definitely diagnosed with angina pectoris. Selected from patients who were attended to Kirkuk general hospital and Azady teaching hospital. Developed questionnaire was constructed for the purpose of the study which consisted of three parts: the demographic data of the respondent, medical data and angina patients knowledge. The data were collected through the use of interview. They were analyzed through the application of descriptive statistical analysis and inferential statistical data analysis.

Results: the findings of the study indicated that $)(55 \%)$ of the samples were in age group ( $\geq 60)$ years, $(53 \%)$ of them were female, $(60 \%)$ of the sample were illiterate, $(30 \%)$ of them were jobless, $(68 \%)$ of the sample were married, (72\%) of the sample had barely sufficient monthly income. Regarding the medical data, the result shows that $(81 \%)$ of the samples has $(\leq 5)$ years duration of the diseases, $(70 \%)$ of them had no family history of angina, (56\%) of them has no working hours, (62\%) of the sample had no history of smoking and $(40 \%)$ of them were over weight.

Conclusions: The study concluded that most of the samples have inadequate knowledge about the etiology of angina, most of the samples have adequate knowledge about the risk factors of angina, most of the samples have adequate knowledge about the Clinical manifestation of angina, most of the them have adequate knowledge about the medical treatment of angina and most of them had inadequate knowledge about the invasive treatment of angina.

Recommendations: The study recommended that the necessity of educational programs should be designed to increase people knowledge about etiology, signs and symptom and treatment of angina pectoris and Providing scientific booklet, publication and journal about angina.

Keywords: Assessment, Knowledge, Angina pectoris, Atherosclerosis, Coronary artery bypass graft, ischemia.

\section{INTRODUCTION}

Angina pectoris is a clinical syndrome usually characterized by episodes or paroxysms of pain or pressure in the anterior chest. The cause is insufficient coronary blood flow, resulting in a decreased oxygen supply when there is increased myocardial demand for oxygen in response to physical exertion or emotional stress. In other words, the need for oxygen exceeds the supply. The severity of angina is based on the precipitating activity and its effect on activities of daily living (Suzanne et. al., 2008).

Angina is a symptom of a condition called myocardial ischemia. It occurs when the heart muscle (myocardium) does not get as much blood as it needs. This usually happens because one or more of the heart's arteries is narrowed or blocked (Suzanne et. al., 2010). Coronary artery disease (CAD) is the most prevalent type of cardiovascular disease in adult, it is important for the nurse to become familiar with various manifestations of coronary artery condition and methods for assessing, preventing and treating these disorders (American Heart Association, 2004). The four leading causes of death globally in 2030 are projected to be ischemic heart disease, cerebrovascular disease (stroke), AIDS and chronic obstructive pulmonary disease (Baron and Storb, 2004). Because of the prevalence of $\mathrm{CAD}$, nursing practicing in any setting across the continuum of care, whether in the home, hospital or rehabilitation facility, must be capable of assessing the cardiovascular system. An accurate and timely assessment of cardiovascular function provides the data necessary to identify nursing diagnosis,

* Assistant Lecturer / College of Nursing/Kirkuk University 
formulating of individualized plan for care, evaluating the response of patient to the care provided. An understanding of the structure and function of the heart in (Gibbons, 2003).

\section{MATERIALS AND METHOD}

The present study was carried out through the application of quantitative design (descriptive study) for angina pectoris patients from 1st of July, 2012, up to the 16th of April, 2013 to assess angina patient's knowledge.

The study was conducted at Kirkuk general and Azadi teaching hospital, which are receiving large number of angina patients. A non-probability (purposive) sample of (100) definitely diagnosed angina pectoris patients, selected from adult patients who were attended to these hospitals.

Through extensive review of relevant literature, a questionnaire was constructed for the purpose of the study with interview technique. Overall items included in the questionnaire were (34) items. A panel of (10) experts was involved in the determination of the questionnaire content validity.

A pilot study was carried out for the period of September 10th to 25th, 2012 to determine the questionnaire reliability through the use of (Test - Retest). The questionnaire consists of three parts, demographic data which is composed of (6) items which is (age, gender, level of education, occupation, marital status, monthly income and residential area), medical data which comprised of (5) items such as (Duration of disease, Working hours, Family History, Smoking, body Mass Index, Exercise) and patients knowledge which comprised of (23) items. That classified as ( Etiology of angina pectoris, Risk factors for angina pectoris, Clinical manifestation, Medical treatment and invasive treatment ). These items were measured, scored and rated of 3-level Likert rating scale; always (3), sometimes (2), never (1).The data were collected through the utilization of constructed questionnaire, interview technique with angina patients in medical wards in kirkuk and azady teaching hospitals.

The data collection process was performed from the period of 17th of October, 2012 up to the 24th November, 2013. Consent informed was granted from patients for participation in the present study was obtained and the interview was carried out individually. The data were analyzed through the application of descriptive statistical analysis which include (frequency and percentage, mean of score) and inferential statistical analysis which include (chisquare).

\section{RESULTS}

Table (1). Distribution of the samples regarding demographic data with frequency and percentage

\begin{tabular}{|l|l|c|c||}
\hline No & Age(years) & Frequency & Percentage \\
\hline 1 & $30-39$ & 3 & 3.0 \\
\hline 2 & $40-49$ & 10 & 10.0 \\
\hline 3 & $50-59$ & 32 & 32.0 \\
\hline 4 & $\geq 60$ & 55 & 55.0 \\
\hline Total & & 100 & 100 \\
\hline & Gender & Frequency & Percentage \\
\hline 1 & Male & 47 & 47.0 \\
\hline 2 & Female & 53 & 53.0 \\
\hline Total & & 100 & 100 \\
\hline No & Level of Education & Frequency & Percentage \\
\hline 1 & (Illiterate) Not read and Write & 60 & 60.0 \\
\hline 2 & Read and Write & 12 & 12.0 \\
\hline 3 & Primary School Graduate & 10 & 10.0 \\
\hline 4 & Intermediate School Graduate & 4 & 4.0 \\
\hline 5 & Secondary School Graduate & 4 & 4.0 \\
\hline 6 & High Institute Graduate & 4 & 4.0 \\
\hline 7 & College and post Graduate & 6 & 6.0 \\
\hline Total & & 100 & 100 \\
\hline No. & Occupation & Frequency & Percentage \\
\hline 1 & Governmental Employed & 13 & 13.0 \\
\hline 2 & Self employed & 12 & 12.0 \\
\hline 3 & Retired & 16 & 16.0 \\
\hline
\end{tabular}




\begin{tabular}{||l|l|c|c||}
\hline 4 & House wife & 29 & 29.0 \\
\hline 5 & jobless & 30 & 30.0 \\
\hline Total & & 100 & 100 \\
\hline No. & Marital Status & Frequency & Percentage \\
\hline 1 & Single & 0 & 0.0 \\
\hline 2 & Married & 68 & 68.0 \\
\hline 3 & Divorced & 1 & 1.0 \\
\hline 4 & Widow/er & 31 & 31.0 \\
\hline Total & & 100 & 100 \\
\hline No. & Monthly income & Frequency & Percentage \\
\hline 1 & Sufficient & 16 & 16.0 \\
\hline 2 & Barely sufficient & 72 & 72.0 \\
\hline 3 & Insufficient & 12 & 12.0 \\
\hline Total & & 100 & 100. \\
\hline
\end{tabular}

Table (1) shows that the highest percentage (55\%) of study sample were at age group $(\geq 60)$ years old, while the lowest percentage (3\%) their ages ranged from (30-39) years old, (53\%) of the study sample were female, $(60 \%)$ of study sample were illiterate, $(30 \%)$ of the study sample were jobless, $(68 \%)$ of the study sample were married, $(72 \%)$ of the study sample have barely sufficient income.

Table (2). Distribution of the samples regarding medical data with frequency and percentage

\begin{tabular}{|l|l|c|c|}
\hline No & Duration of the diseases & Frequency & Percentage \\
\hline 1 & $\leq 5$ & 81 & 81.0 \\
\hline 2 & $6-10$ & 12 & 12.0 \\
\hline 3 & $11-15$ & 6 & 6.0 \\
\hline 4 & $\geq 16$ years & 1 & 1.0 \\
\hline Total & & 100 & 100 \\
\hline No & Family History for angina & Frequency & Percentage \\
\hline 1 & Yes & 30 & 30.0 \\
\hline 2 & No & 70 & 70.0 \\
\hline Total & & 100 & 100 \\
\hline No & Working hours & Frequency & Percentage \\
\hline 1 & Has no working hours & 56 & 56.0 \\
\hline 2 & Less than 8 hours & 21 & 21.0 \\
\hline 3 & More than 8 hours & 23 & 23.0 \\
\hline Total & & 100 & 100 \\
\hline No & Smoking & Frequency & Percentage \\
\hline 1 & Yes & 22 & 22.0 \\
\hline 2 & No & 62 & 62.0 \\
\hline 3 & Ex-smoker & 16 & 16.0 \\
\hline Total & & 100 & 100 \\
\hline No. & Body Mass Index & Frequency & Percentage \\
\hline 1 & Under weight & 0 & 0 \\
\hline 2 & Normal weight & 24 & 24.0 \\
\hline 3 & Over weight & 40 & 40.0 \\
\hline 4 & Obese & 30 & 30.0 \\
\hline 5 & Morbidity obese & 6 & 6.0 \\
\hline Total & & 100 & 100 \\
\hline
\end{tabular}

Table (2) shows that $(81 \%)$ of study sample were have $(\leq 5)$ duration of the diseases, $(70 \%)$ of the patents do not have family history of angina, (56\%) of the study sample don't have working hours, (62\%) of the sample do not smoking, (40\%) of study sample were over weight. 
Table (3). Distribution of patients knowledge with frequency and percentage.

\begin{tabular}{|c|c|c|c|c|c|c|c|c|c|}
\hline \multirow{2}{*}{ No } & \multirow{2}{*}{ Etiology of angina pectoris } & \multicolumn{2}{|c|}{ Always } & \multicolumn{2}{|c|}{ Some times } & \multicolumn{2}{|c|}{ Never } & \multirow{2}{*}{ MS } & \multirow{2}{*}{$S$} \\
\hline & & $\mathrm{F}$ & $\%$ & $\mathrm{~F}$ & $\%$ & $\mathrm{~F}$ & $\%$ & & \\
\hline 1 & $\begin{array}{l}\text { Do you know that Atherosclerosis causes } \\
\text { angina pectoris }\end{array}$ & 26 & 26.0 & 13 & 13.0 & 61 & 61.0 & 1.65 & $\mathrm{LS}$ \\
\hline 2 & $\begin{array}{l}\text { Do you know that Vasospasm lead to } \\
\text { angina pectoris }\end{array}$ & 24 & 24.0 & 7 & 7.0 & 69 & 69.0 & 1.45 & LS \\
\hline 3 & $\begin{array}{l}\text { Do you know that valve lesion causes } \\
\text { angina pectoris }\end{array}$ & 32 & 32.0 & 12 & 12.0 & 56 & 56.0 & 1.76 & $\mathrm{LS}$ \\
\hline \multirow[t]{3}{*}{4} & $\begin{array}{l}\text { Do you know that activity may lead to } \\
\text { angina pectoris }\end{array}$ & 68 & 68.0 & 6 & 6.0 & 26 & 26.0 & 2.42 & HS \\
\hline & Dicl foctore for onoing notoric & \multicolumn{2}{|c|}{ Always } & \multicolumn{2}{|c|}{ Some times } & \multicolumn{2}{|c|}{ Never } & \multirow{2}{*}{ MS } & \multirow{2}{*}{$\mathrm{S}$} \\
\hline & KISK ractors lor angina pectons & $\mathrm{F}$ & $\%$ & $\mathrm{~F}$ & $\%$ & $\mathrm{~F}$ & $\%$ & & \\
\hline 1 & $\begin{array}{l}\text { Do you know that smoking is risk factor } \\
\text { for angina pectoris }\end{array}$ & 96 & 96.0 & 1 & 1.0 & 3 & 3.0 & 2.93 & HS \\
\hline 2 & $\begin{array}{l}\text { Do you know that stress is risk factor for } \\
\text { angina pectoris }\end{array}$ & 100 & 100 & 0 & 0.0 & 0 & 0.0 & 3.0 & HS \\
\hline 3 & $\begin{array}{l}\text { Do you know that alcohol is risk factor } \\
\text { for angina pectoris }\end{array}$ & 86 & 86.0 & 2 & 2.0 & 12 & 12.0 & 2.74 & HS \\
\hline 4 & $\begin{array}{l}\text { Do you know the Obesity is risk factor } \\
\text { for angina pectoris }\end{array}$ & 94 & 94.0 & 0 & 0.0 & 6 & 6.0 & 2.88 & HS \\
\hline 5 & $\begin{array}{l}\text { Do you know some drug cause angina } \\
\text { pectoris }\end{array}$ & 69 & 69.0 & 3 & 3.0 & 28 & 28.0 & 2.41 & HS \\
\hline \multirow[t]{3}{*}{6} & $\begin{array}{l}\text { Do you know that Diet contain high } \\
\text { cholesterol and sodium are risk factor for } \\
\text { angina pectoris }\end{array}$ & 98 & 98.0 & 0 & 0.0 & 2 & 2.0 & 2.96 & HS \\
\hline & Clinicol monifectotion & \multicolumn{2}{|c|}{ Always } & \multicolumn{2}{|c|}{ Some times } & \multicolumn{2}{|c|}{ Never } & \multirow{2}{*}{ MS } & \multirow{2}{*}{$\mathrm{S}$} \\
\hline & - & $\mathrm{F}$ & $\%$ & $\mathrm{~F}$ & $\%$ & $\mathrm{~F}$ & $\%$ & & \\
\hline 1 & $\begin{array}{l}\text { Do you know that substernal pain is } \\
\text { Clinical manifestation of angina pectoris }\end{array}$ & 90 & 90.0 & 1 & 1.0 & 9 & 9.0 & 2.81 & HS \\
\hline 2 & $\begin{array}{l}\text { Do you know that dyspnea is Clinical } \\
\text { manifestation of angina pectoris }\end{array}$ & 87 & 87.0 & 6 & 6.0 & 7 & 7.0 & 2.80 & HS \\
\hline 3 & $\begin{array}{l}\text { Do you know the palpitation is Clinical } \\
\text { manifestation of angina pectoris }\end{array}$ & 75 & 75.0 & 10 & 10.0 & 15 & 15.0 & 2.36 & MS \\
\hline \multirow[t]{3}{*}{4} & $\begin{array}{l}\text { Do you know that sweating is Clinical } \\
\text { manifestation of angina pectoris }\end{array}$ & 82 & 82.0 & 8 & 8.0 & 10 & 10.0 & 2.72 & HS \\
\hline & medical treetment & \multicolumn{2}{|c|}{ Always } & \multicolumn{2}{|c|}{ Some times } & \multicolumn{2}{|c|}{ Never } & \multirow{2}{*}{ MS } & \multirow{2}{*}{$\mathrm{S}$} \\
\hline & mearcal treatment & $\mathrm{F}$ & $\%$ & $\mathrm{~F}$ & $\%$ & $\mathrm{~F}$ & $\%$ & & \\
\hline 1 & Oxygen therapy & 83 & 83.0 & 7 & 7.0 & 10 & 10.0 & 2.73 & HS \\
\hline 2 & Medication like nitroglycerin & 90 & 90.0 & 4 & 4.0 & 6 & 6.0 & 2.84 & HS \\
\hline 3 & Rest as soon as possible & 100 & 100 & 0 & 0.0 & 0 & 0.0 & 3.00 & HS \\
\hline 4 & Semi fowler position & 64 & 64.0 & 6 & 6.6 & 30 & 30.0 & 2.34 & $\mathrm{MS}$ \\
\hline \multirow[t]{3}{*}{5} & $\begin{array}{l}\text { Diet contain low calorie, low sodium and } \\
\text { low cholesterol }\end{array}$ & 94 & 94.0 & 2 & 2.0 & 4 & 4.0 & 2.90 & HS \\
\hline & Invasive treatment & \multicolumn{2}{|c|}{ Always } & \multicolumn{2}{|c|}{ Some times } & & ver & MS & $S$ \\
\hline & Invasive treatment & $\mathrm{F}$ & $\%$ & $\mathrm{~F}$ & $\%$ & $\mathrm{~F}$ & $\%$ & MS & $\mathrm{S}$ \\
\hline 1 & $\begin{array}{lll}\text { Percutanous } & \text { Transluminal } & \text { Coronary } \\
\text { angioplasty } & & \end{array}$ & 59 & 59.0 & 5 & 5.0 & 36 & 36.0 & 2.33 & MS \\
\hline 2 & Stent placement & 30 & 30.0 & 3 & 3.3 & 67 & 67.0 & 1.63 & $\mathrm{LS}$ \\
\hline 3 & Atherectomy & 30 & 30.0 & 6 & 6.0 & 64 & 64.0 & 1.66 & $\mathrm{LS}$ \\
\hline 4 & Coronary artery bypass surgery & 67 & 67.0 & 2 & 2.0 & 31 & 31.0 & 2.36 & MS \\
\hline
\end{tabular}

The table (3). shows patients knowledge regarding etiology of angina pectoris, it indicate that the mean of score was high significant in item 4 and low significant other items. Regarding the risk factors the table show that mean of score was high significant in all items. For the clinical manifestation, the 
table show that mean of score was high in items $(1,2,4)$ while it is moderate significant in item 3 . Regarding medical treatment the table showthat mean of scores was high significant in items $(I, 2,3,5)$ while moderate significant in item 4 . Also the table indicate that the mean of score of invasive treatment was moderate significant in items $(1,4)$ while it was low significant in items $(2,3)$.

Table (4). Relationship between angina patient's age and their knowledge.

\begin{tabular}{||l|l|c|c|c|c||}
\hline \hline \multirow{2}{*}{ Scores } & Age & Always & Sometimes & Never & \multirow{2}{*}{ Total } \\
\cline { 4 - 7 } & & $\mathrm{F}$ & $\mathrm{F}$ & $\mathrm{F}$ & \\
\hline 2 & $30-39$ years & 32 & 3 & 14 & 49 \\
\hline 3 & $40-49$ years & 152 & 12 & 36 & 200 \\
\hline 4 & $50-59$ years & 447 & 39 & 200 & 686 \\
\hline Total & $\geq 60$ years & 766 & 120 & 479 & 1365 \\
\hline X2obs=39.896 & $\mathrm{df}=6$ & 1397 & 174 & 729 & 2300 \\
\hline \hline
\end{tabular}

$\mathrm{df}=$ degree of freedom; P-value $=$ Level of probability at $\mathrm{p}=0.05 ; \chi^{2}=$ Chi-square

Table (4) shows that there is a highly significant relationship between angina pectoris age and their knowledge at $\mathrm{P}<0.05$

Table (5). Relationship between angina pectoris gender and their knowledge.

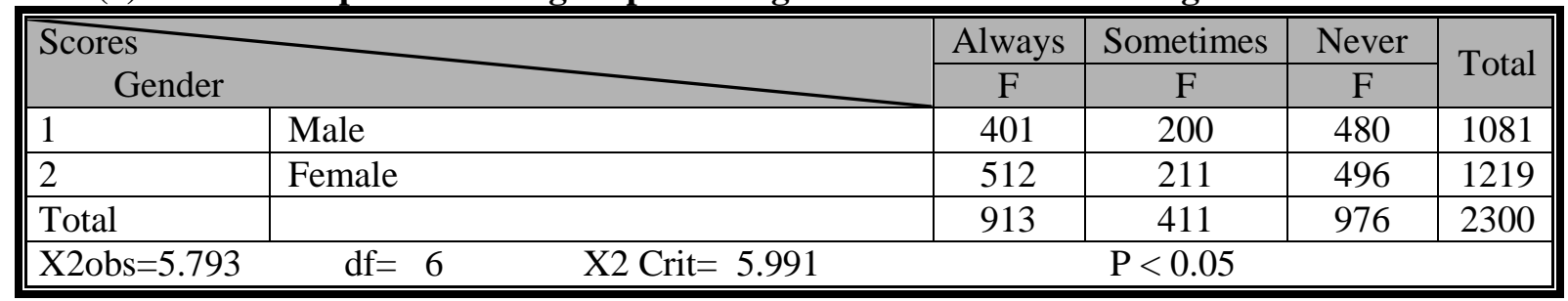

$\mathrm{df}=$ degree of freedom; P-value $=$ Level of probability at $\mathrm{p}=0.05 ; \chi 2=$ Chi-square

Table (5) shows that there is no significant relationship between angina pectoris gender and their knowledge at $\mathrm{P}<0.05$

Table (6). Relationship between angina patients level of education and their knowledge.

\begin{tabular}{|c|c|c|c|c|c|}
\hline \multirow{2}{*}{\multicolumn{2}{|c|}{$\begin{array}{l}\text { Scores } \\
\text { Level of education }\end{array}$}} & \multirow{3}{*}{$\begin{array}{c}\text { Always } \\
\text { F } \\
735\end{array}$} & \multirow{3}{*}{$\begin{array}{c}\text { Sometimes } \\
\mathrm{F} \\
69\end{array}$} & \multirow{3}{*}{$\begin{array}{c}\text { Never } \\
\text { F } \\
576\end{array}$} & \multirow{3}{*}{$\begin{array}{l}\text { Total } \\
1380\end{array}$} \\
\hline & & & & & \\
\hline 1 & Illiterate & & & & \\
\hline 2 & Read and Write & 147 & 13 & 116 & 276 \\
\hline 3 & Primary School Graduate & 149 & 7 & 74 & 230 \\
\hline 4 & Intermediate School Graduate & 60 & 6 & 26 & 92 \\
\hline 5 & Secondary School Graduate & 55 & 10 & 27 & 92 \\
\hline 6 & High Institute Graduate & 65 & 3 & 24 & 92 \\
\hline 7 & College and post Graduate & 90 & 24 & 24 & 138 \\
\hline Total & & 1301 & 132 & 867 & 2300 \\
\hline $\mathrm{X} 2 \mathrm{obs}=86.54$ & $\mathrm{X} 2$ Crit $=$ & & $\mathrm{P}<0.05$ & & \\
\hline
\end{tabular}

$\mathrm{df}=$ degree of freedom; P-value $=$ Level of probability at $\mathrm{p}=0.05 ; \chi 2=$ Chi-square

Table (6) shows that there is a highly significant relationship between angina pectoris level of education and their knowledge at $\mathrm{P}<0.05$.

\section{DISCUSSION}

Table (1) indicated the findings of the study which revealed that $(55 \%)$ of angina patients age were $(\geq 60)$ years old, the mean of the age was (53) years, majority of the study was females accounted (53\%). Majority of them were illiterate $(60 \%)$, most of the study sample were jobless (30), majority of the samples were married, majority of the study had barely sufficient income(72\%). It is statistically true that older people tend to have angina pectoris more than younger people. However this does not mean that getting older inevitably leads to angina pectoris (Office of Disease Prevention and Health Promotion, 2010). Before to about age 55, women have a lower incidence of angina pectoris and other cardiovascular disease than men. But women's risk for angina pectoris will 
rise more sharply with age 55 years old. This pattern may be partly explained by hormonal differences between sexes, estrogen tend to protect women against cardiovascular including angina pectoris (Pearson et. al., 2003).

Regarding medical data in (table 2), the result shows that $(81 \%)$ of the samples has $(\leq$ $5)$ years duration of the diseases, $(70 \%)$ of them had no family history of angina, (56\%) of them has no working hours, (62\%) of the sample had no history of smoking and (40\%) of them were over weight. the researcher explanation of the result that most of the samples have $(\leq 5)$ duration of angina is that angina pectoris is a very serious problem and has many serious complication which is ( myocardial infarction, heart failure, arrhythmias, heart attack, and death) and these complications lead to premature death). the incidence of systemic disease, such as hypertension, heart failure, diabetics, chronic renal failure and cancer increases with advanced age, predisposing older age to angina pectoris associated with these disorders (Milgrom et. al., 2004). The risk of angina pectoris is five times higher in the obese compared to those of normal weight and up to two-third of cases can be attributed to excess weight. More than $85 \%$ of cases occur in those with a body mass index (BMI) greater than 25 (Eagle and Guyton, 2004).

Table (3) show patient's knowledge, regarding the etiology of angina pectoris, the study indicate that the mean of score was high significant in item (4) and low significant other items. angina is associated with a significant obstruction of a major coronary artery, normally the myocardium extracts a large amount of oxygen from the coronary circulation to meet its continuous demands (Cleveland, 2003). Regarding the risk factors the table show that mean of score was high significant in all items. Rsearch suggests that damage to the inner layers of the coronary arteries caused CAD. Smoking, high level of fat and cholesterol in the blood, high blood pressure and high level of sugar in the bloodcan damage the coronary arteries (Fraker et.al., 2007). For the clinical manifestation, the table show that mean of score was high in items $(1,2,4)$ while it is moderate significant in item (3). Typical angina is uncomfortable pressure, fullness, squeezing or pain in the center of the chest, the discomfort may be felt in the neck, jaw, shoulder, back or arm (Grundy et. al., 2004).

Regarding medical treatment the table show that mean of scores was high significant in all items except item (4) was moderate significant. Also the table indicate that the mean of score of invasive treatment was moderate significant in items $(1,4)$ while it was low significant in items $(2,3)$. There are several treatment option for people with stable angina, these option are classified as medical treatment (which include medications and life style modifications) or intervention treatment (surgical treatment with percutaneous coronary intervention, with or without stent, or coronary artery pass graft surgery). The choice among these treatment options need many individual factors including a persons age, the severity of coronary heart disease, the relatively risks and benefits of various treatment, the presence of other medical condition (Marshall and Soucy, 2003).

\section{CONCLUSION}

The result concluded that most of the angina pectoris patients were $(\geq 60)$ year's old represent $(55 \%)$, (53) of them were female, $(60 \%)$ of them were illiterate, $(30 \%)$ of the sample were jobless, $(68 \%)$ of them were married, $(72 \%)$ of them has barely sufficient income. Majority of the samples have $(\leq 5)$ Duration of the diseases, $(70 \%)$ of them has no family history of angina, $(56 \%)$ of the sample has no working hours, (62\%) of the sample do not smoking and (40\%) of them were over weight. Finally, the results show that there is highly significant relation between angina pectoris patients age and their knowledge, no significant relationship between angina pectoris gender and their knowledge, also the study concluded that there is highly significant relation between angina pectoris patients level of education and their knowledge.

\section{RECOMMENDATIONS}

The study recommends that educational programs should be designed to increase people knowledge about etiology, signs and symptom and treatment of angina pectoris. Additionally, specify a modern center for dealing with angina pectoris. Providing scientific booklet, publication and journal about angina. Advertisements and some healt educational programs regarding angina pectoris should be encouraged through mass media. Further study has to be conducted in all Kirkuk region. Finally, secondary school curriculum should include topics concerning angina pectoris.

\section{REFERENCES}

Suzanne C. Smeltzer, Brenda G. Bare, Janice L. Hinkle and Kerry H. Cheever . (2008). 
Text book of medical-surgical nursing. (11 Ed.). Lippincott williama and wilkins. P.p. 867

Suzanne C. Smeltzer, Brenda G. Bare, Janice L. Hinkle and Kerry H. Cheever. (2010). Handbook for Brunner and Suddarth's textbook of medical-surgical nursing. (12th Ed.). Wolters Kluwer Health / Lippincott Williams and Wilkins. P.p.756.

American Heart Association. (2004). Heart disease and stroke statistics. Dallas, TX: American Heart Association. www.AmericanHeartAssociation.com Baron, F. and Storb S. (2004). Allogeneic hematopoietic cell transplantation as treatment for hematological malignancies: A review. Springer Seminars in Immunopathology. 26(1-2).P.p.71-94.

Gibbons, R. J. (2003). ACC/AHA guideline update for the management of patients with chronic stable angina: A report of the American College of Cardiology/American Heart Association Task Force on Practice Guidelines. Circulation. 107(1). P.p. 149-158.

Office of Disease Prevention and Health Promotion. (2010). Healthy People. U.S. Departmentof Health and Human Services, 200 Independence Ave., SW, Washington, DC 20201; 1-800-877-6966775; http://www.health .gov/ healthy people.

Pearson, T., Mensah, G. A., and Alexander, R. W. (2003). Markers of inflammation and cardiovascular disease. A statement for health care professionals from the Centers for Disease Control and Prevention and the American Heart Association. Circulation. 107(3). P.p. 499-511.

Milgrom, L. B., Brooks, J. A., Qi, R., et al. (2004). Pain levels experienced with activities after cardiac surgery. American Journal of Critical Care. 13(2). P.p.116125.

Eagle, K. A., and Guyton, R. A. (2004). ACC/AHA 2004 guideline update for coronary artery bypass graft surgery: Summary article. A report of the American College of Cardiology/American Heart Association Task Force on Practice Guidelines (Committee to update the 1999 Guidelines for Coronary Artery Bypass Graft Surgery). Circulation. 110(14). P.p.1-9.

Cleveland, K. W. (2003). Argatroban: A new treatment option for heparin- induced thrombocytopenia. Critical Care Nurse. 23(6). P.p. 61-69.

Fraker TD Jr, Fihn SD, Gibbons RJ et. al. (2007). "chronic angina focused update of the ACC/AHA 2002 guidelines for the management of patients with chronic stable angina: ". J Am Coll Cardiol. 50 (2264): 12.

Grundy, S. M., Cleeman, J. I., Merz, N. B., et al. (2004). Implications of recent clinical trials for the national cholesterol education program Adult Treatment Panel III guidelines. Circulation. 110(2). P.p. 227-239

Marshall, M. C., and Soucy, M. D. (2003). Delirium in the intensive care unit. Critical Care Nursing Quarterly. 26(3). P.p.172-178. 